\title{
Local wisdom of coastal communities in mitigating earthquake disaster risk reduction
}

\author{
Putri Febri Wialdi ${ }^{1 *}$, Roni Ekha Putera $^{1}$, Kusdarini ${ }^{1}$, Ria Ariany ${ }^{1}$, Tengku Rika Valentina ${ }^{2}$, and Rifki Dermawan ${ }^{3}$ \\ ${ }^{1}$ Department of Public Administration, Faculty of Social and Political Science, Andalas University \\ ${ }^{2}$ Department of Political Science, Faculty of Social and Political Science, Andalas Universitasy \\ ${ }^{3}$ MSc International Relations, School of Sociology, Politics, And International Studies, Bristol University, The United Kingdom
}

\begin{abstract}
The purpose of this study was to describe how the application of the mitigation of earthquakes for coastal communities by indigenous communities coast of Padang. This study uses interviews and literature. The reduction is one of the measures for reducing disaster risks through physical development as well as awareness and increase the capacity of communities to deal with the threat of disaster. Disaster management can be viewed from different angles, one of them with mitigation based on local wisdom (Local Wisdom) to reduce the risk of earthquakes. Mitigation models based on local knowledge are the study of disaster by using the approach of positivism, where the application can not be separated from social and cultural methods in facing disasters and use natural signs as an early warning system. West Sumatra is one of the provinces which are in an area prone to natural disasters earthquakes. Where several districts/cities in West Sumatra are located in the area will be exposed to the phenomenon of earthquake megathrust, one of Padang. Therefore, it needs improvement in disaster management in the face of disaster.
\end{abstract}

\section{Introduction}

The National Agency for Disaster Management (BNPB) states that the trend of natural disasters in Indonesia, in general, has increased in recent years. Located in the Pacific ring of fire, or also known as the Pacific circumference, and flanked by three tectonic plates of the world, namely the Indo Australian, Eurasian, and Pacific plates, Indonesia is a disaster-prone country.[3]

In Indonesia, disaster is no longer considered an extraordinary event because it occurs almost at any time, whether it is a natural disaster such as an earthquake, volcano, flood, hurricane, and forest fire, or man-made disaster such as building fire and collapse. According to the result of the study by BNPB (2014), most of the disasters in Indonesia are caused by environmental damage, for example, flash floods in several regions such as Wasior in Papua and Pangkalan Subdistrict in Lima Puluh Kota District. Due to this high level of vulnerability and susceptibility to disasters, policy on disaster risk reduction is important to minimize property loss and casualties. Based on the data from BNPB (2011), West Sumatra Province is ranked 6th in the list of disaster vulnerabilities because of the geographical conditions of several districts and cities, located in coastal areas directly adjacent to the Indian Ocean. Therefore, 7 of 19 districts/cities have high levels of vulnerability and susceptibility to earthquake and tsunami threats, namely Padang Pariaman, Pasaman, Mentawai Islands, Pesisir Selatan, Pasaman Barat, Pariaman, and Padang. [3].
BNPB considers that the level of preparedness of the community and local government is facing and responding to natural disasters remains low and not optimal. This issue needs to be addressed to reduce disaster risk and minimize the worst possibility. Disaster management in the future needs to be conducted from now on.

Currently, Law No 24 of 2007 concerning Disaster Management is the legal basis for any activities of disaster risk reduction in Indonesia, wherein the regulation states that disaster management must be carried out comprehensively. Referring to this regulation, changes are made to institutions that handle and coordinate with each other regarding disaster management at both national and regional levels.

The province of West Sumatra, tectonically located in the western region of Indonesia, is a highly dynamic region. The subduction/interaction of 2 plates, namely the IndoAustralian plate and Eurasian plate, causes West Sumatra to be prone to disasters such as earthquakes and tsunami.

Currently, there is a heated discussion among the public regarding the megathrust earthquake that is estimated to have a magnitude of $8.9 \mathrm{SR}$ and will hit several areas of West Sumatra, including Padang. Due to its location in a subduction zone, Padang has a source of destructive earthquakes. Furthermore, based on the disaster risk index graph compiled by BNPB from 34 provinces, Padang is a city on the island of Sumatra with a high level of risk of earthquake and tsunami.

Disaster management in West Sumatra Province has been regulated in West Sumatra Provincial Regulation

\footnotetext{
*Corresponding Author: putriwialdi@gmail.com
} 
Number 5 of 2007 concerning Disaster Management. Meanwhile, disaster management in Padang has been regulated through the Regulation of the Mayor of Padang No. 25 of 2018 on Fixed Procedures for Disaster Management. Referring to the Presidential Regulation No 64 of 2010 concerning Disaster Mitigation in Coastal Areas and Small Islands, coastal areas and small islands have a high risk of earthquake and tsunami, thus requiring the government to carry out disaster management and include mitigation in the management of coastal areas and small islands that contains social, economic, and cultural aspects of the community.

Disaster mitigation must be carried out in a planned and comprehensive manner. Therefore, several approaches are necessary, namely technical, human, administrative, and cultural approaches. Local wisdom is the asset of the community that can be utilized to cope with disasters. Thus, the government as the leading sector in disaster mitigation can learn how to save the community, prevent disasters and reduce the risk or impact of disasters through local wisdom. Local wisdom has long existed and developed before the modern technology-based early warning system. The cultural approach through local wisdom has been proven to successfully help Acehnese people in reading coastal natural phenomena and save thousands of them from the tsunami hitting Simulue Island as well as residents around Mount Kelud in reading the initial signs of the eruption of Mount Kelud through animal behavior [15].

In addition, coastal communities generally have their own belief and tradition, including traditional ceremonies based on coastal cultures that have existed from generation to generation. In Padang, there are several areas with their tradition of warding off misfortune (tolak bala), namely Pantai Air Manis in Padang Selatan Subdistrict and Bungus Teluk Kabung Subdistrict. This ritual is carried out annually every Sha'ban month by the local community as a special means of asking for safety from tsunami and earthquake disasters.

By carrying out mitigation based on local wisdom, the government positions the community and community groups as the main actors in carrying out disaster management. According to Wiwik Ratna Kusumasari, community-based disaster management can be realized supposing there are motivators, clear concepts, the appropriate language of popular communication based on local wisdom, and easily accessible information networks. It is also in line with the current study by BNPB that intensively integrates local wisdom in disaster mitigation.

There are three actors or elements involved in the framework of comprehensive disaster management, namely the government, private sector, and the community. Their involvement is an important issue. As stipulated in Law No. 24 of 2007 Article 16 Paragraph (3), the activities of preparedness are the responsibility of the Government and local government and implemented together by the public and private sectors. Meanwhile, the Government Regulation No. 21 of 2008 on the Implementation of Disaster Management mentions that the implementation of disaster management is a series of efforts covering the determination of development policies at risk of disaster, the activities of disaster prevention, emergency response, and rehabilitation.

In the implementation of disaster management in a region, multi-stakeholders are involved, both from the government (from the lowest to the highest level of government, from the village to the center), the legislature, Non-Governmental Organizations (both local and foreign), and private sectors. Institutional institutions formed in the context of disaster risk reduction in Padang are well defined and complete because mostly all institutions engaged in the field of disaster are available in Padang. In this case, BPBDPK as the leading sector should be able to manage existing institutions.

The purpose of this study was to describe the implementation and process of Earth and Tsunami Disaster Mitigation Based on Local Wisdom for the Coastal Community of Padang City.

\section{Literature Review and Hypothesis Development}

\subsection{Disaster Mitigation}

Disaster mitigation is defined as an activity or an action to reduce the impact of a disaster as well as the efforts to minimalize casualties and property damage when the disaster occurs. In carrying out disaster mitigation, it is necessary to conduct a disaster risk assessment of the area To calculate the disaster risk of the area, we must know the hazard, the vulnerability, and the capacity of the area. Disaster mitigation is the obligation of various government parties, experts, and communities. In addition, disaster mitigation should be carried out continuously and routinely long before the disaster occurs [7] In addition, mitigation is also defined as an action aimed at reducing the impact of natural or man-made disasters on a nation or community.

Disaster mitigation must be carried out in a planned and comprehensive manner through various efforts and approaches, among others [8]

\subsubsection{Technical Approach}

Technically, disaster mitigation is carried out to reduce the impact of a disaster, for example by.

1. Creating a solid design of earthquake-resistant buildings.

2. Creating disaster-resistant materials, for example, fire-resistant materials.

3. Creating a technical safety design, for example, a flood embankment.

\subsubsection{Human Approach}

The human approach is aimed at forming people who understand and are aware of the dangers of disasters. Therefore, human behavior and way of life must be improved and adapted to environmental conditions and potential disasters faced. 


\subsubsection{Administrative Approach}

The government or organizational leadership can take an administrative approach in disaster management, especially at the mitigation stage. For example, by conducting disaster risk analysis in making permits and conducting disaster studies.

\subsubsection{Cultural Approach}

There is still an opinion among the public that disaster is destiny, thus it must be accepted as it is. It is not entirely true, because with the ability to think and act, humans can attempt to avoid disasters as well as reduce the risks caused. Therefore, we need a cultural approach to raise awareness about disasters. Through a cultural approach, disaster prevention is adjusted to the local wisdom of the community that has been established for a long time.

Disaster risk management and reduction are adapted to the culture and traditions that develop in the community. This approach should be utilized by the government to develop local culture and traditions to build disaster awareness in the community.

In carrying out disaster mitigation, W.N Carter divides mitigation into two concepts, namely nonstructural and structural mitigation. Nonstructural mitigation is conducted as follows [1].
a) Creating a legal framework
b) Establishing institutions
c) Increasing public awareness
d) Conducting training and education
e) Providing incentives
f) Providing warning system

\subsection{Local Wisdom}

Local wisdom is all forms of knowledge, belief, understanding, or insight as well as customs or ethics that guide human behavior in living in an ecological community [2] Local wisdom that applies in a community has a positive impact on facing and responding to the coming disaster. Local wisdom is an extraction of various experiences of the ancestors who have experienced a disaster, passed down from generation to generation [11]. In addition, local wisdom is believed to have a contribution in terms of community participation that is expected to run sustainably by understanding local knowledge, local technology, local culture, and local traditions that can contribute to disaster mitigation [11].

Studies on disaster and disaster management can be carried out with a positivist approach. The studies on disasters using a positivism approach are inseparable from the theme of socio-culture and community, particularly about to with concerning community responses to disasters (Adaptive Capacity) and the ability to make adjustments and provide feedback in dealing with natural disasters [5].

The empirical experience of the community in a long and continuous period time on various kinds of processes, environmental dynamics with geomorphic processes and their results, and disaster events provide extensive and in- depth experience and knowledge to the community. This experience also plays a role in shaping and providing wisdom to the community in their interactions with the nature and the environment [5].

Local wisdom can play a role and provide a real contribution to overcome risks that may arise due to physical processes of (disasters). Moreover, it is believed to be able to support the sustainability of human life after a disaster [5]

\section{Research Methodology}

This research applies a qualitative approach. using techniques. Collecting data through observation, and interviews (structured or unstructured), documentation, and visual materials and designing protocols for recording information

\section{Results And Discussions}

Currently, there is a heated discussion among the public regarding the megathrust earthquake that is estimated to have a magnitude of $8.9 \mathrm{SR}$ and will hit several areas of West Sumatra, including Padang. Due to its location in a subduction zone, Padang has a source of destructive earthquakes, tsunamis, and other natural disasters. It is evident from the disaster risk index graph in Indonesia presented in Fig. 1. Referring to the graph, Padang is a city in the island of Sumatra with a high level of risk for earthquakes and tsunami.

Fig. 1. Disaster Risk Index in Indonesia

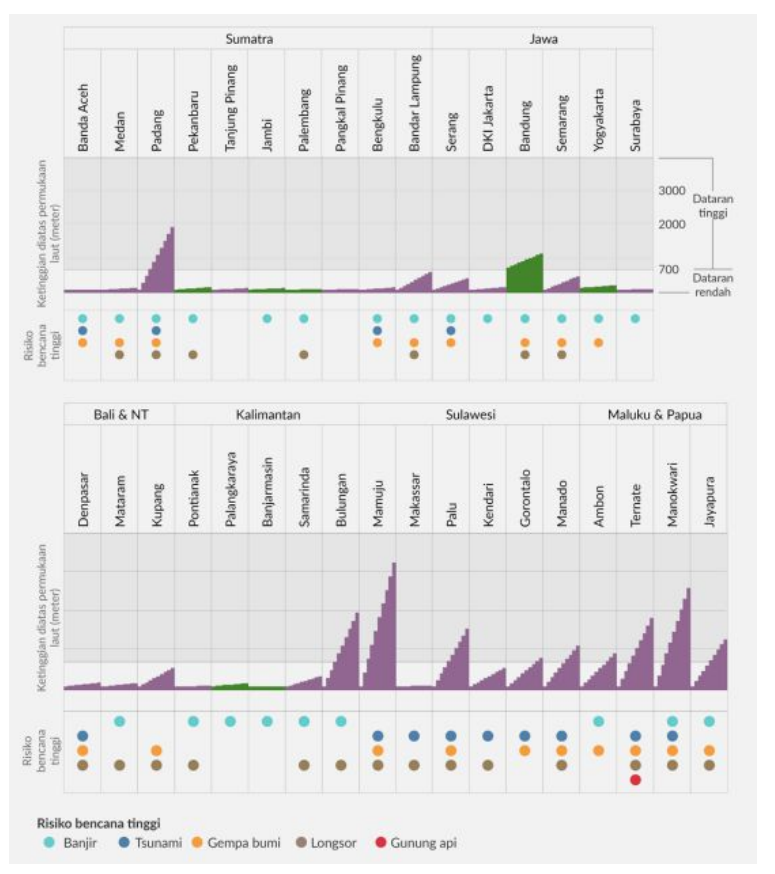

It is by following under in accordance with the statement conveyed by the head of BNPB, Lieutenant General Doni Manardo, in the agenda of the BNPB work visit to West Sumatra. The people of Padang, Mentawai, and several districts/cities located on the West Coast of Sumatra are supposed to be prepared to face the Megathrust 
phenomenon. It is also in compliance with the data compiled by the Regional Agency for Disaster Management (BPBD) of Padang regarding the population affected by the earthquake and tsunami in districts/cities located in the West Coast region of Sumatra, as presented in table 1.

Table 1. Affected Population in Districts/Cities in the West Coast of Sumatra, 2017

\begin{tabular}{|c|c|c|c|c|c|}
\hline \multirow[t]{2}{*}{ No } & \multirow{2}{*}{$\begin{array}{c}\text { District/ } \\
\text { Cities }\end{array}$} & \multicolumn{4}{|c|}{ Total Number } \\
\hline & & $\begin{array}{l}\text { Subdis } \\
\text { ctricts }\end{array}$ & $\begin{array}{l}\text { Village/ } \\
\text { Nagari }\end{array}$ & $\begin{array}{c}\text { Popul } \\
\text { tion(Pe } \\
\text { ople) }\end{array}$ & $\begin{array}{c}\text { Popul } \\
\text { ation } \\
(\%)\end{array}$ \\
\hline 1 & $\begin{array}{l}\text { Pesisir } \\
\text { Selatan } \\
\text { District }\end{array}$ & 15 & 182 & $\begin{array}{c}245,91 \\
6\end{array}$ & $\begin{array}{c}43.26 \\
\%\end{array}$ \\
\hline 2 & $\begin{array}{l}\text { City of } \\
\text { Padang }\end{array}$ & 11 & 104 & $\begin{array}{c}508,80 \\
4\end{array}$ & $\begin{array}{c}58.38 \\
\%\end{array}$ \\
\hline 3 & $\begin{array}{c}\text { Padang } \\
\text { Pariaman } \\
\text { District }\end{array}$ & 17 & 103 & 24,861 & $5.23 \%$ \\
\hline 4 & $\begin{array}{c}\text { City of } \\
\text { Pariaman }\end{array}$ & 4 & 71 & 25,029 & $\begin{array}{c}27.94 \\
\%\end{array}$ \\
\hline 5 & $\begin{array}{l}\text { Agam } \\
\text { District }\end{array}$ & 16 & 82 & 20,644 & $3.81 \%$ \\
\hline 6 & $\begin{array}{c}\text { Pasaman } \\
\text { Barat } \\
\text { District }\end{array}$ & 11 & 19 & 78,782 & $\begin{array}{c}17.69 \\
\%\end{array}$ \\
\hline 7 & $\begin{array}{c}\text { Mentawai } \\
\text { District }\end{array}$ & 10 & 43 & 17,313 & $\begin{array}{c}16.40 \\
\%\end{array}$ \\
\hline
\end{tabular}

Referring to Table 1, Padang, a city located along the west coastline, has the highest percentage of population among 7 districts or cities on the West Coast of Sumatra that is affected by the earthquake and tsunami. Furthermore, the research conducted by the Indonesian Association of Disaster Experts (IAKI) discovers that Padang is one of the cities prone to earthquakes and tsunamis (Radarmalang.id, 2019). Thus, to reduce disaster risk, the community must take mitigation and preparedness measures, starting with increasing public understanding and improving infrastructure, socialization, early warning system, and guidance to the community.

Disaster management in Padang has been regulated through the Regulation of the Mayor of Padang No. 25 of 2018 on Fixed Procedures for Disaster Management. This policy serves as the guideline for the government in improving disaster management in Padang. However, preparedness and mitigation measures from related parties and the community are also essential.

In compliance with the Presidential Regulation No 64 of 2010 concerning Disaster Mitigation in Coastal Areas and Small Islands, coastal areas and small islands have a high risk of earthquake and tsunami, thus requiring the government to carry out disaster management and include mitigation in the management of coastal areas and small islands that contains social, economic, and cultural aspects of the community [11].
Table . Potential Tsunami Hazard Areas in several sub-districts in Padang City in 2017

\begin{tabular}{|c|c|c|c|c|c|c|c|}
\hline \multirow{2}{*}{ NO } & \multirow{2}{*}{\begin{tabular}{|c|} 
Kecamat \\
an \\
\end{tabular}} & \multicolumn{4}{|c|}{ Luas Bahaya (HA) } & \multicolumn{2}{|c|}{ Bahaya } \\
\hline & & \begin{tabular}{|c|}
$\begin{array}{c}\text { Renda } \\
h\end{array}$ \\
\end{tabular} & \begin{tabular}{|c|} 
Seda \\
ng
\end{tabular} & $\begin{array}{c}\text { Ting } \\
\text { gi }\end{array}$ & \begin{tabular}{|c|} 
Tota \\
1
\end{tabular} & Indeks & Kelas \\
\hline 1 & \begin{tabular}{|l|} 
Bungus \\
Teluk \\
Kabung
\end{tabular} & 109 & 507 & 807 & $\begin{array}{c}1.42 \\
3\end{array}$ & 0,944 & Tinggi \\
\hline 2 & \begin{tabular}{|l} 
Koto \\
Tangah
\end{tabular} & 271 & 692 & $\begin{array}{c}2.34 \\
6\end{array}$ & $\begin{array}{c}3.30 \\
9\end{array}$ & 0,778 & Tinggi \\
\hline 3 & Kuranji & 298 & 307 & 16 & 621 & 0,476 & Sedang \\
\hline 4 & \begin{tabular}{|l|} 
Lubuk \\
Begalung
\end{tabular} & 96 & 53 & 62 & 211 & 0,300 & Rendah \\
\hline 5 & \begin{tabular}{|l|} 
Lubuk \\
Kilangan
\end{tabular} & - & - & 42 & 42 & 0,596 & Sedang \\
\hline 6 & $\begin{array}{l}\text { Nanggal } \\
\mathrm{o}\end{array}$ & 160 & 608 & 80 & 848 & 0,666 & Sedang \\
\hline 7 & \begin{tabular}{|l|} 
Padang \\
Barat
\end{tabular} & 20 & 165 & 289 & 475 & 0,926 & Tinggi \\
\hline 8 & $\begin{array}{l}\text { Padang } \\
\text { Selatan }\end{array}$ & 151 & 114 & 200 & 465 & 0,727 & Tinggi \\
\hline 9 & \begin{tabular}{|l|} 
Padang \\
Timur \\
\end{tabular} & 141 & 405 & 34 & 580 & 0,566 & Sedang \\
\hline 10 & $\begin{array}{l}\text { Padang } \\
\text { Utara }\end{array}$ & 44 & 287 & 415 & 747 & 0,905 & Tinggi \\
\hline 11 & Pauh & - & - & - & - & - & Rendah \\
\hline & $\begin{array}{l}\text { KOTA } \\
\text { ADANG }\end{array}$ & $\begin{array}{c}1.289,2 \\
5 \\
\end{array}$ & \begin{tabular}{|c|}
3.138 \\
, 48 \\
\end{tabular} & $\begin{array}{l}4.29 \\
2,28 \\
\end{array}$ & $\begin{array}{l}8.72 \\
0,01 \\
\end{array}$ & 0,688 & Tinggi \\
\hline
\end{tabular}

By improving the system and strengthening earthquake and tsunami disaster mitigation in coastal areas, it is hoped that the government and the community can carry out rescue independently and utilize the main infrastructure as a gathering place or a shelter when the 8.9 SR megathrust earthquake hits and causes a tsunami in Padang and other coastal areas. Padang has two areas located in the coastal area and the red zone of an earthquake that is at risk of tsunami, namely Padang Selatan and Bungus Teluk Kabung Subdistricts.

Disaster mitigation, according to Presidential Regulation No 21 of 2008 concerning the Implementation of Disaster Management, is one of the ways or actions to reduce disaster risk, either through physical development as well as awareness and increased capacity in dealing with disaster threats. Disaster mitigation is divided into two, namely structural and nonstructural mitigation. Nonstructural mitigation is a method or effort to reduce the risk of disaster by empowering and providing good knowledge to the community [10].

Meanwhile, according to W.N Carter, mitigation is part of the pre-disaster stage in the disaster management cycle. In disaster mitigation, there are efforts or actions taken by the government and the community to reduce the impact caused by disasters. Carter divides disaster mitigation into structural and nonstructural mitigation [1] . One example of structural mitigation carried out by the government is constructing buildings used as shelters. Currently, there are several buildings in Padang that are used as shelters, namely government buildings, banks, 
hotels, and other buildings whose construction is intended as shelters, one of which is located in Parupuk Tabing. However, several areas in Padang are still considered to have a shortage of shelters. It is confirmed by the Head of General Affairs Subsection of BPBD of Padang on initial observations.

"It is true that the number of tsunami shelters in several areas of Padang City is currently still limited. It is due to budget constraints and limited land since building a shelter requires location and in-depth study. Therefore, it is hoped that the community can utilize the natural shelters provided by their surrounding environment, such as in Bungus Teluk Kabung, Pantai Air Manis, and the hilly areas in Mount Pangilun." (Interview with Firdaus, the Head of General Affairs Subsection of BPBD of Padang, on May 6, 2019)

Meanwhile, W.N Carter divides nonstructural mitigation into several activities, one of which is the establishment of institutions or organizational groups that are aware of disasters [1]. Observed from this aspect, Padang currently has several organizational groups formed by the government whose duties and functions serve as an extension of the government in carrying out disaster management.

Based on the Decree of the Chief Executive of BPDB of Padang No 229 of 2017 concerning the Appointment of Volunteers Providing Disaster Information (Roll Call) in Padang, it is determined that the disaster personnel/members/volunteers are ready to assist BPDB of Padang in providing information regarding disaster in each subdistrict and village. BPBD of Padang has appointed Disaster Preparedness Groups comprising 2,080 members in 104 villages in 11 subdistricts in Padang (SK KP BPBD Padang City No 229, 2017).

According to W.N Carter, the next activity of nonstructural mitigation is effectively increasing disaster management and public awareness of disasters since disaster mitigation activities require community participation [1]. Based on the observation, the community living in the coastal areas in Padang Selatan and Bungus Teluk Kabung Subdistricts understand the risk of earthquake and tsunami disasters that may occur in their areas. They have an early warning system derived from local wisdom that has been ingrained among coastal communities, namely reading the natural conditions.

“... we already understand the risk of an earthquake that might have a potential for a tsunami. Therefore, in general, we have carried out government instructions to prepare disaster preparedness bags, considering we are located in the red zone of the tsunami." (Interview with Yelierni, the member of Air Manis Coastal community, on June 15, 2019)

Based on the interview above, it is obvious that the people living in Air Manis Coastal area are aware of the risk of disasters that may occur in their settlements, thus they have carried out the instructions of BPDB. Implementing good disaster mitigation does not only require community awareness, but also the knowledge related to disaster management, for example how to apply mitigation measures developing in the local culture of the community [1]. Therefore, training and education for the community regarding good disaster management are necessary, one of which is disaster mitigation. It is confirmed by the Head of General Affairs Subsection of BPBD of Padang on initial observations.

"Conducting training and education related to disaster mitigation for the community is the most important pillar in disaster mitigation. Therefore, by involving related parties currently, BPBD establishes several activities including socialization related to massive disaster mitigation, particularly to the community living in coastal areas, since, shelter is not the only main issue in reducing the risks of earthquake and tsunami disasters." (Interview with Firdaus, the Head of General Affairs Subsection of BPBD of Padang, on May 6, 2019)

Currently, there is still a lack of education and public understanding of disaster mitigation. Therefore, a method is needed to empower the community. For example, a more ingrained model that provides optimal results in shaping a culture of disaster mitigation in Indonesia, specifically Padang, considering that disaster mitigation has not been utilized as a local culture in the community at large. Disaster mitigation must be carried out in a planned and comprehensive manner. Therefore, several approaches are necessary, namely technical, human, administrative, and cultural approaches [8]. Local wisdom is the asset of the community that can be utilized to cope with disasters.

Thus, the government as the leading sector in disaster mitigation can learn how to save the community, prevent disasters and reduce the risk or impact of disasters through local wisdom. Local wisdom has long existed and developed prior to the modern technology-based early warning system.

The cultural approach through local wisdom has been proven to successfully help Acehnese people in reading coastal natural phenomena and save thousands of them from the tsunami hitting Simulue Island as well as residents around Mount Kelud in reading the initial signs of the eruption of Mount Kelud through animal behavior [15].

In addition, coastal communities generally have their own belief and tradition, including traditional ceremonies based on coastal cultures that have existed from generation to generation. In Padang, there are several areas with their tradition of warding off misfortune (tolak bala), namely Pantai Air Manis in Padang Selatan Subdistrict and Bungus Teluk Kabung Subdistrict. This ritual is carried out annually every Sha'ban month by the local community as a special means of asking for safety from the tsunami and earthquake disasters. By following the statement given by the Security and Order and Disaster Management Section in Bungus Teluk Kabung Subdistrict:

"As government officials of Bungus Teluk Kabung Subdistrict, we fully support every event or tradition that has existed for a long time, one of which is the annual tradition of warding off misfortune (tolak bala). Particularly in Bungus Teluk Kabung Subdistrict, this tradition is performed to encourage the community to return to the philosophy of Adat Basandi Syarak, Syarak Basandi Kitabullah. As community representatives, we believe that Bungus Teluk Kabung can be free from all threatening misfortune such as earthquake and tsunami 
disasters through this tradition." (Interview with Rustam, the Head of Welfare and Disaster Management Section on 02 July 2019)

In Bungus Teluk Kabung Subdistrict, the tradition of warding off misfortune involves religious scholars such as sheiks, subdistrict government officials, Mayor of Padang Mahyeldi, Al Quran Education Park (TPQ) or Madrasah Diniyah Awaliyah (MDA), mosque youth, and majelis taklim. The event begins with a joint parade, followed by dhikr before sunset and evening prayers in the congregation and closed by al tarekat.

Similarly, South Padang Subdistrict also has a tradition of warding off misfortune held in Pantai Air Manis Village. The traditional ceremony called Raba'akia is attended by several adat figures, the community, and government leaders such as the Head of the Tourism Office.

In Padang, earthquake and tsunami disaster mitigation by utilizing local wisdom has also been implemented or utilized by BPBD of Padang as the leading sector in carrying out disaster prevention and management to ensure the safety and security of the people of Padang from natural disasters such as earthquakes and tsunamis. It is confirmed by Firdaus, the Head of General Affairs Subsection of BPBD of Padang, as follows.

"The local wisdom of the community is the most important and prioritized method for mitigating natural disasters such as earthquakes, tsunamis, and floods since mitigation based on local wisdom is expected to be able to provide an early warning system to the community before to the disaster, considering the limitations of BPBD of Padang in providing early warnings to the community during disasters. Therefore, mitigation based on local wisdom needs to be highlighted in carrying out disaster mitigation." (Interview with Firdaus, the Head of General Affairs Subsection of BPBD of Padang, on May 6, 2019)

Implementing mitigation based on local wisdom obviously requires an understanding of the earthquake and tsunami disasters, followed by an understanding of methods or steps to be taken when the disasters occur. Therefore, the cooperation of every stakeholder involved is necessary as it is impossible to fully delegate these activities solely to the government or individuals. By following the statement of the Head of General Affairs Subsection of BPBD of Padang Firdaus that:

"To mitigate the earthquake and tsunami disasters, socialization has been carried out to make the public aware of the importance of mitigation and understand what actions to be taken when an earthquake with a potential for tsunami occurs in Padang, both at the community and at the education level. The importance of mitigation based on local wisdom has also been socialized through community groups, such as Disaster Preparedness Group (KSB) both at the village level and at the subdistrict level. In addition, several NGOs, such as Tsunami Preparedness Community (KOGAMI), are also established due to the limited ability of BPBD of Padang to reach the community directly." (Interview with Firdaus, the Head of General Affairs Subsection of BPBD of Padang, on May 6 2019, at 10.30 WIB.)
It is by following the findings of a study conducted by Zulfadrim, Toyoda, and Kanegae entitled "The implementation of Local Wisdom in Reducing Natural Disaster Risk: A Case Study Form West Sumatra". Yang states that the community an urban and rural areas in Minangkabau has developed ways to prevent or reduce disaster risk by well adaptation and preparation. Their ancestors had experienced a recurrent hydrometeorological disasters and utilized their knowledge to anticipate the disaster. The most interesting feature about the Minangkabau community is their traditional house. Most people know about the traditional houses of West Sumatra with a unique triangular roof. This traditional house is called Rumah Gadang (Big House) because of its function as the main venue for several activities as well as a place for clan meetings and marriages. This house is built on stilts with high space from the ground to protect the community from flood, animal attack, and moisture and frequently to keep their stock of cattle. This traditional house is also able to withstand an earthquake since the column of this building is normally laid in stone foundation rather than inserted into the soil [16].

Referring to the research conducted by Zulfadrim, it is evident that disaster mitigation based on local wisdom has long been applied by the Minang community, observed from how their ancestors built Rumah Gadang equipped with rangkiang to store their food and livestock to prepare themselves for disasters.

Furthermore, based on the findings of this research, it is observed that people living in coastal areas such as Pantai Air Manis Village in South Padang Subdistrict and 6 villages in Padang Selatan Subdistrict, in general, have an early warning system by utilizing the megaphone in the mosque (surau) in their neighborhood. During long-last and severe disasters, the mosque keeper, also known as "garin masjid", will provide instructions for the community to evacuate to the hills in the two areas.

The existence of an early warning system based on local wisdom is considered capable of providing benefits in increasing activities for reducing the risk that will be caused by disasters, as it is known that there are limitations in the ability of the government to prepare and provide an easily accessible and understandable warning system for the community.

However, positioning the mosque keeper as the actor who will provide information related to disasters requires the mosque keeper to have good education and training related to disasters, for example by providing opportunities for them to be involved in disaster activities that have been carried out by the government. However, until 2019, it has not been carried out yet.

By carrying out mitigation based on local wisdom, the government positions the community and community groups as the main actors in carrying out disaster management. According to Wiwik Ratna Kusumasari, community-based disaster management can be realized supposing there are motivators, clear concepts, appropriate language of popular communication based on local wisdom, and easily accessible information networks. In the application of this model, the actors carrying out mitigation activities based on local wisdom are community groups, consisting of traditional leaders such 
as KAN and niniak mamak, religious leaders, and KSB of Subdistricts and Villages as the extension of BPBD.

\section{Conclusion}

In general, the government has provided support by making policies or regulations related to mitigation as guidelines in carrying out disaster management. However, these policies or regulations have only been studied in general. In addition, there are absolutely no clear rules regarding guidelines for mitigation by utilizing cultural aspects.

To facilitate the implementation of mitigation based on local wisdom, the government has formed communitybased institutions to assist in implementing mitigation and increasing the role of the community in disaster mitigation. However, the government does not collaborate with outside organizations such as KAN and WALHI. Mitigation based on local wisdom will be more optimal supposing the government collaborates with these two institutions.

The community in the coastal area has understood the actual measures in disaster mitigation. However, in practice, people living in coastal areas tend to be more aware than people living in hilly areas. People living in coastal areas have carried out government instructions, one of which is preparing Disaster Preparedness Bags. This is inversely proportional to the people living far from the shoreline, feeling that they live in safer areas.

Therefore, it is necessary to increase training and education related to disaster mitigation for the community in this region. However, the education and training do not progress well and are optimal. Until 2019, training and education related to mitigation in Pantai Air Manis Village is carried out by house-to-house visits. Similar activity is carried out in 5 of 6 villages in Bungus Teluk Kabung Subdistrict. It leaves only 1 village, namely Teluk Kabung Tengah, as the only village holding training activities by involving stakeholders in the village.

It is caused by the limited budget provided by the government to the Forum for Disaster Preparedness Groups, both at the subdistrict and village levels. Can be overcome by utilizing the tradition of warding off misfortune as a forum for educating the public regarding disaster mitigation, considering that this tradition is carried annually in both regions and is attended by many people in the area. In addition, the government and FKSB can also take advantage of the existence of KAN and the culture of "returning to surau" to apply mitigation methods by utilizing local wisdom to optimize the implementation of mitigation.

\section{Limitation And Study Forward}

In this study, the researcher limits the mitigation study described or reviewed only from the nonstructural aspects of mitigation according to the field of public administration. This study is expected to provide contribute to the government of Padang to further appreciate the local wisdom of the community that can be used as a method for carrying out earthquake disaster management.

We would like to express our gratitude to the parties who contributed to the completion of this research. The completion of this research is inseparable from the contribution of several government agencies of Padang that have been willing to become the informants in this study. In addition, we would like to thank the informants from various circles of society who were willing to be interviewed as well as the parties involved in providing ideas, criticism, and input to complement this research.

\section{References}

1 W. N.. Carter, Disaster management: A Disaster Manager's Handbook. Mandaluyong City, Manila: Asian Development Bank (2008)

2 M. Desfandi, The urgency of local wisdom-based disaster education curriculum in Indonesia. Socio Didactics, 1(2). Dec 2014. Journal.uinjkt.ac.id/index.php/sosio-Fitk. (2014)

3 https://bnpb.go.id/

4 B. Kusumasari,. \& Q. Alam,. Local wisdom-based disaster recovery model in Indonesia. Disaster Prevention and Management, 21(3), 359-369 Law No 24 of 2007 concerning Disaster Management (2012)

5 .Marfai. Introduction to environmental ethics and local wisdom. Yogyakarta: Gajah Mada University Press. (2012)

6 N. Putera, \& Sugandi Synergizing stakeholder in reducing risk of earthquake and tsunami-disaster in the most vulnerable area. International Journal of Administrative Science \& Organization, 23(3) (2016)

7 R. E. Putera,. Mitigation of earthquake risk reduction from the perspective of policy implementation. PT RajaGrafindo Persada: Depok. (2018)

8 S. Ramli,. Practical guidelines for disaster management. Jakarta: PT Dian Rakyat. (2010)

9 The Decree of the Mayor of Padang No 122 of 2018 concerning the Forum for the Disaster Preparedness Group for the period 2018-2023.

10 The Presidential Regulation No 21 of 2008 concerning the Implementation of Disaster Management.

11 The Presidential Regulation No 64 of 2010 concerning Disaster Mitigation in Coastal Areas and Small Islands.

12 The Regulation of the Mayor of Padang No. 25 of 2018 on Fixed Procedures for Disaster Management.

13 Wikantiyoso, R. (2010). Disaster mitigation in urban areas; adaptation or anticipation of urban planning and design. The potential of local wisdom in urban planning and design for disaster mitigation efforts, local wisdom. 2. 1 (2010)

14 www.bnbp.go.id/uploads/24/buku-rbi.pdf

15 L. Zamzami, \& Hendrawati. The local cultural wisdom of the maritime community for disaster mitigation efforts in West Sumatra (Research Article, Andalas University, Padang). (2011)

16 Zulfadrim, Y .Toyoda, \& H Kanegae. The implementation of local wisdom in reducing natural disaster risk: A case study from West Sumatera. Osaka, Japan. (2018) 